Journal of Social and Development Sciences (ISSN 2221-1152)

Vol. 6, No. 3, pp. 15-23, September 2015

\title{
Impact Analysis of the Village Fund Allocation (ADD) Toward Economic Community (Case Study on the Rural District of Namlea Siahoni), Buru Regency
}

\author{
Hayati Hehamahua \\ Universitas Iqra Buru, Indonesia \\ Nurhayati_heha@yahoo.com
}

\begin{abstract}
Rural development is the subject of development, as the movement of people in carrying out development based on the awareness to improve life better, given more than $60 \%$ of Indonesia's population lives in the village. The position is a strategic village a capital base that must be understood as a whole and integrated, both in terms of strengths, weaknesses, opportunities and constraints, as well as relationships with strategic environment, regional, national and international. Strategic implications of independence of the village in the welfare society is still a big question, because the village government's ability to use the budget. This study intends to investigate whether the allocation of funds village (ADD) to contribute to the economic empowerment. With institutional economics approach, the findings of this study are: Directional distribution of ADD for this can be seen from the reality that most of the village allocates its budget ADD to repair /improvement of physical roads, buildings, irrigation. Low contribution in encouraging community development and very little village which directs its budget for financing ADD more productive example BUMDes formation, Village Bank, and the Village Market. Capital revolving loan without interest for the development activities of small and medium enterprises as well.
\end{abstract}

Kayword: Rural development, local government, allocation of funds village (ADD). institutional economics approach, qualitative analysis

\section{Introcuction}

Indonesia development strategy is an increase in the distribution of development and their fruits through sectoral development policy and the performance of the public, especially in rural areas. Rural development is the subject of development, as the movement of people in carrying out development based on the awareness to improve life better, given more than $60 \%$ of Indonesia's population lives in the village. With a population of the above and supported by potential natural components are appropriately gets a small village by village fund allocation (ADD). If the allocations of village funds are used to improve the lives and welfare of the community, it can be said the gap between rural and urban areas can be realized. Reflecting the development of rural communities in the past, especially in the New Order era, rural development is the development of methods and approaches centrally programmed state. Since the Law No.32 of 2004 on local government was passed, local governments have greater authority in the management of the area. The emergence of Law has changed the paradigm of centralized to decentralized development. Administrative village is the smallest form of government, led by the village head of a direct election. Formally, the government has issued PP No.72 of 2005 on the village as the basic law governing all things considered urgent for the village. By definition, based on the regulation of village or another as defined as the unity of the legal community that has boundaries with the authority to regulate and manage the interests of the local community, based on the origins and customs that recognized and respected in the administration system of the Republic of Indonesia .

In rural development, the village government serves as a subsystem of the system of government administration in Indonesia, so the village has the authority, duties and obligations to regulate and manage the interests of their own community. In organizes the authority, duties and obligations of the village in governance and development needed source of revenue village. If more thoroughly understood, the village is a meeting place of the current government policies and aspirations of the people. In other words, the village is a place of realization of cooperation between the Government and the community in implementing development. In this sense, the village has a strategic position in governance, development, and community 
service. The position is a strategic village a capital base that must be understood as a whole and integrated, both in terms of strengths, weaknesses, opportunities and constraints, as well as relationships with strategic environment, both regionally, nationally and internationally. Therefore, there needs to be the core strategy for the village's independence. Based on this understanding, the village has a strategic position that requires equal attention to the implementation of regional autonomy. In order to strengthen the implementation of the Government to support the embodiment of the village and regional autonomy, it is appropriate to the village to get right to manage its own finances. One form of the government's concern for the development of the rural area is the development budget specifically set forth in Annggaran Income and Expenditure (budget) for the development of rural areas, namely in the form of Village Allocation Fund (ADD) as has been presented at the beginning. May be analogous to a village fund allocation DAU / DAK for the Village, the village fund allocation is a major source of financing because of limited revenue village.

The expected stakeholders Village, Village Head is positioned primarily as a stimulant ADD to community empowerment and not only on the development of physical infrastructure useful short term/small contribution to the empowerment of communities or even more as a source of income for the village officials. Village funds are used to fund rural governance and economic empowerment of rural communities. Accordingly, the financial management of the village was carried out by the village head as outlined in the village regulations on budget revenue and expenditure village. In an effort to increase the role of village government in providing basic services to the community and community empowerment, rural government funding should be supported in carrying out their duties either in government or in the field of development. As an illustration, to the village which has the potential sources of revenue from the fishing community (fishermen), will be better and more useful when in the wake of the village market, rather than the existing budget each year just to repair the road or a building renovation village hall. According Maryunani (2007), accelerating the development of the rural economy, particularly those in disadvantaged areas, should be a priority and priority. Because characterized by centralized empowerment will not be able to touch the specific characteristics of the existing order, and tend to or potentially will ignore the order characteristics. Empowerment with the principle of centralization, deterministic, and homogeneous is a policy that was in turn left (Jaya, 2010). In the past, top-down development policies which tend too much central government intervened to development activities in the area. This resulted in the fragility of the region's economy and the severity of the economic disparities between regions and segments of society, because it is not deeply rooted in regional development.

\section{Literature Review}

Village Fund Allocation: Allocation of funds village or ADD is part of village funds for the results obtained from local taxes and parts of Central and Regional Balance Funds received by the District. According to the Minister of the Interior regulations No. 37 Year 2007 on guidelines for the financial management of the village in paragraph 18 that the allocation of funds derived from the village of District / City sourced from the fund balance and regional Financial Center received by District / City for at least 10\% (ten percent). Allocation of funds village or village called special allocation allocated by the Government through the local government (district). Ultimate purpose is to improve development and socio-economic progress of society. Listening to the results of the revision of Law No. 22 of 1999 affirms, is the village of Finance is all the rights and obligations of the village which can be valued in money, and everything in cash or in the form of goods that can be used in connection with the implementation of the village belongs to the rights and obligations that give rise to income, and financial management of the village. Financial management of the Village Fund Allocation is an important part that is not separated from the financial management of the village in APBDes. All activities funded by the Village Fund Allocation planned, implemented and evaluated openly engage the village community. Village Allocation Fund is intended to finance the village government in carrying out the activities of government and human resource development and improvement of the economy in rural communities.

Village Allocation Funds are needed because of the decentralization and delegation of authority of village autonomy is to provide public services and the implementation of village governance in accordance with regulations-regulations applicable. Based on the principle of money follow function, then the function is executed village administration must be accompanied by the funding aspect. Mangkoesubroto (1999: 169) 
states government expenditure reflects government policy. If the government has set a policy to purchase goods and services of government expenditure reflect the costs to be incurred by the government to implement the policy. In line with the Devas (1999: 4-8) states local government spending is increasing because of the demands of public service spending is increasing. The demand is growing because it is influenced by population growth that requires services from the government. So it does not happen what was said by Soetrisno (1988), the dominance of the village heads in rural development programs, has ignored the aspirations and participation of rural communities that ultimately led to the demise of the political independence of the construction of the village itself. Allocation of funds actual village was instrumental in the implementation of regional autonomy, because of Villages is at the forefront of implementing government services to the community. In addition, the Villages is government closest to the people in carrying out public services, public regulation, and empowerment.

Village Government has the right to autonomous indigenous autonomy based on the authority entitled to regulate and manage the interests of the community. This can be understood by the issuance of various policies Regional Regulation of the village, so there is diversity of the village arrangement causes the type, form, and content of authority varies greatly from one region to another in accordance origins and customs of the local community. Allocation of funds such as the village of diverse, it provides for different treatment. This indicates that the management of the Village Fund Allocation should not be tightly regulated by government regulation, but still provides ample room for the regional regulation. Management of Village Allocation Fund is not limited to divide the funds, but also implies the movement of villagers in planning, conducting, and accountability. It is certainly necessary technical preparations mature, not only by the government but also the village of the district. Of course, it takes understanding and agreement of various parties, because each district and village will have characteristics of each. Allocation of funds village (ADD) will encourage the implementation of village autonomy, as well as government efforts to empower rural and village communities, the Provincial and District Government as a facilitator, facilitating rural communities to be able to carry out the construction of the village. With the allocation of village funds focused on the development of rural communities are expected to encourage some handling problems faced by rural communities independently without having to wait a long time coming of local government programs.

Autonomy Regional: The term autonomy comes from the Yunani autos meaning him and namos which means the Act or rules. Thus autonomy can be interpreted as the authority to regulate and manage the household itself (Suryaningrat, 1985). Opinion expressed Hoesein (1993:75) autonomy is a government by and for the people in the national territory of a State informally located outside the central government. Meanwhile, according Mawhood (1983), autonomy is a local government has the authority to own the separate existence with the authority given by the government to allocate a substantial source of material resources of different functions. Having the freedom to take the initiative is a basis for the granting of regional autonomy, as the basis for regional autonomy is able to act in accordance with local requirements. There are also groups that interpret local autonomy as a mechanism for empowerment. According to the group autonomy should be more accommodating various local interests and local agencies and for the necessary authority. Thus, special deals in the division of tasks / affairs are handled by the central government and are handled by the regional (local). Variations interpretation of the concept of autonomy is due to the different theobfjcnvmcvnvretical reference. Theoretically the term autonomy has many meanings, which led to various interpretations

Selznick (1992), see autonomy as a strategy to maintain the integrity of an institution in which the values and potential of these institutions are protected. There fore autonomy indirectly holds the recognition of the existence and power of local elites. While the autonomy interpreted by Holdaway, Newberry, Hickson dan Heron, as the number of decision-making authority held by an organization (see Price and Mueller, 1986: 40). The more the level of authority of the higher level decision making autonomy. interpret autonomy as The Degree to Which and Organization Has Power with Respects to Its Environment (see Price and Mueller, 1986: 40). In this case, the distinction between Government and business organizations. In this case to differentiated between government and business. Power here interpreted as "influence" or "control". In this context of regional autonomy is interpreted to how much a local government to control the activities of the fulfillment of the interests of local communities from the influence of the environment. Another meaning is expressed by Dworkin, 1998 (see Terry, 1995: 49) as the circumstances in which people create and organize 
the regulation itself. Of course this is based on the meaning of the word "auto" which means self and "nomos" which means the rule of law. With this meaning of autonomy can be interpreted as a self-regulating authority or independence. There are perceived autonomy as the principle of respect for restricted public life in accordance customs and history of its properties in the context of a unitary state (Supomo in Abdullah, 2000: 11).

Institutional Economics: Economics as a discipline can be seen as a symptom of economic phenomena as the way people or communities meet their needs for goods and services that are rare through the process of production, consumption, and transactions. By itself the fulfillment of their needs or in economic activity, a person will be in contact with social institutions such as markets, hospitals, family and so on. Todaro (1998) adds economic development has been outlined back to base reduce or eliminate poverty, inequality and unemployment in the context of economic growth or emerging economies. Meanwhile institutional economics discuss economic issues in the realm of economic and social relations in society. Nort defines institutions as rules created by humans to organize and form a political interaction, social and economic. The rules consist of formal rules such as laws, the constitution, and the informal rules such as social norms, and customs. Institutional economics is a discipline that studies the economy with not ignores the non-economic aspects such as culture, politics, law and others that in the conventional economy is considered no. Black (2002), institutional economics emphasizes the importance of the institutional aspect in determining how the economic system and social work. In this context, the management of the village fund allocation needs to pay attention to the economic and social life of the community in order to increase the independence of the individuals of the village community. Hayami and Kikuchi (1987), defines institutions as rules do with sanctions by community members to facilitate coordination and cooperation among people who use the resource. It is also affirmed by the Hasibuan (2003) the main core of the flow of institutional economics is seeing economics with a unity of social sciences, such as psychology, sociology, politics, anthropology, history, and law.

Proponents of institutional economics believes that a multidisciplinary approach is essential for photographing economic problems, such as social, legal, political, cultural, and so forth as a unit of analysis. It signaled that the rules that have been poured into the village autonomy law and finance division between the center and the regions to give power or authority for villagers to organize and participate in the economic sector and development. In this the community as owners of production factors into economic development actors themselves. However, in practice there are other factors that affect the individual / community in making decisions such as social, political, and so forth. Institutional economics approach gives a solution how to understand a complex social process (Hehamahua, 2012: 23). In line with the existence of institutions (institutions) to be important for economic development, when many people interact (transactions) in playing their respective roles. In line with the existence of institutions to be important for economic development, when many people interact (transaction) with their respective roles. In these conditions, institutional seen as rules that provide shade and sanctions against individuals and groups to make his choice. Meanings such as is in accordance with the opinion of

Commons (1934: 96) which defines the institutional as "collective action in restraint, liberation, and expansion of individual action".

Bardhan and Nort in Yustika (2006: 40-41), said the institution would be more accurate when defined as social rules, agreements and other elements of the structural framework of social interaction. Similarly according to North (1990) is the institutional rules and norms are created in a society that determines the dos and don'ts as well as the duties and that should be done or not done. In the life of society as a complex system, the economics just as one part or sub system alone. Therefore, to better understand aspects of the economic life of society, it needs to be connected between economic factors with other factors in the life of the community. Othes factors mentioned for example; cultural factors, group solidarity, and social stratification, which is believed to be much direct impact on economic development. In factor culture for example the are values that encourage economic development, but on the other hand there is also a value that hampers economic development. It is appropriate that in said Stiglitz (2003) in Ismail (2007: 2) that is empires, capitalist economy has been able to create a very high income for mankind. But at the same time, the capitalist economy also produces negative effects are no less fierce. In observing changes in economic and social as well as political, experts use different labels and different theoretical categories to describe the 
characteristics and structure of the old society that is becoming obsolete, and the new social order that is being formed. Within the framework of regional economic development, economic decentralization is not just a financial division between central and local government, but most do not have to be translated into the three aspects of major changes (Rahmanta, 2009: 5). First, the management of economic development (planning, financing, implementation, and evaluation) that were previously dominated central government transferred authority to local governments. The central government does not need too much direct intervention in the economic development of the area, but need to be given the flexibility to local governments to be creative and take the initiative in economic development in their respective regions.

Second, privatization implementation of economic development. In the past, the development policies centralized or top-down, government tends to be too much to handle and organize economic activities that could be handled more efficiently by the private or the public, either individually or through a business entity. The role of government is too dominant in economic development in addition to wasting the use of the state budget, also has many deadly economic creativity of the people and local institutions. The old paradigm that considers the construction is as if it is a "masterpiece" the government should be changed to the construction of a people's creativity. Third, economic development organizations and institutions also have to undergo a change. In the past, to "produce" top down development policies, governments often forming new organizations and institutions (which by the government considered modern) and "marginalize" organizations and local institutions. To overhaul the country was less dynamic, but still with respect to the order of the local community in maintaining togetherness with introducing and incorporating elements of urbanism in certain rural order. This means that rather than population / rural communities invest in the city, the better the villagers are encouraged to stay in their own communities with the means to invest in a rural environment. In the sense that if the budget allocation of the village was given as a stimulant to encourage and finance the construction of the village, as has been presented at the beginning. So precisely establish the village market or set up a Village Bank to accelerate the process of economic development of rural communities. He hope is that the velocity of money in circulation in the village will be income for rural development. Thus the economic development of rural communities will turn into a prosperous society (independent and prosperous economy in the autonomy). In addition to the regional development of the rural economy, can also reduce conflicts or gaps between people in urban and rural communities. Because the regional economic development within the framework of national economic development is to make the region's economy as the backbone of the national economy.

\section{Methodology}

Research Approach: Based on preliminary research and phenomena, this research uses a qualitative approach in institutional economics perspective. Qualitative research departed from the philosophy of constructivism which assumes that the fact that plural dimension, and an interactive social experience exchange interpreted by individuals (Sukmadita, 2006:60). Qualitative research is aimed at understanding social phenomena from the perspective of participants. Qualitative researches believe that truth is dynamic and can be found only through a review of the people through their interaction with their social situation (Danim, 2002).The social structure is understood as a complex situation that requires in-depth explanation and interpretation. In this condition the institutional economics approach provides a way out of how to understand a complex social process, whereas qualitative research provides a method for correcting deeply causality of the process (Yustika, 2006: 100). Qualitative research is a model of humanistic research, which puts humans as the main subject in the event of social / cultural. Humanist nature of qualitative research can be seen from the view of the human position as a major determinant of individual behavior and social phenomena. Qualitative research is aimed at understanding social phenomena from the perspective of participants. Participants are people who are invited to interview, observation, were asked to provide the data, opinions, thoughts, perceptions (Sukmadinata, 2006: 94). Specifically, the relationship between institutional economics approach to qualitative research methods can be mapped as follows; institutional economic analysis attach great importance to the structure of power (economic, social, political, cultural, legal and others) who live in the community, so it affects the individual / group to make decisions exchange / transaction. 
Data Collection: The data used in this study using several methods: first, unstructured interviews (not using questionnaires). It is certainly expected to be able to explore further why each person has a different angle to each other.

Validity Test Data: To know that the data obtained is valid, or the data obtained provide information about the actual situation or relevant and contain important information. So in testing the correctness of the information, the researcher uses triangulation technique, which uses multiple sources of information in order to verify and strengthen the data, both in the different methods of data collection and use of information support. According Moleong (2007: 330), triangulation is a technique that utilizes data validity checking something else.

Analysis Unit: If the political and social structures that do not support it distortion of economic processes in a society. The unit of analysis in this study is a village fund allocation (ADD) which involves the parties (actors) in it. Referred to as the unit of analysis is something that is made the object of research.

Data Analysis: With appreciation or understanding of the behavior of one's interpretive community in this case the interaction between the parties (actors), then the behavior is the realization of the views or thoughts on the person.

\section{Results}

Village Fund Allocation; Economic Community: ADD as an embodiment of decentralization in rural areas of financial management should give a better impact on rural development. To make independence (autonomy) village, it takes two carrying capacity. First, the decentralization of the country that divides power, authority, financial, trust and responsibility to the village. Second, the local base that grows in the village (self, social capital, indigenous and local institutions, capacity, and economic resources. In the context of economic, regional autonomy on the one hand have to ensure smooth implementation of national economic policy in the region and on the other hand opening up opportunities for local governments to develop regional and local policies to optimize the utilization of economic potential in the region. Village Allocation Fund is no longer a help but a revenue sharing funds or the balance between the district and the village, as the result of levies and taxes as well as parts of equalization funds obtained districts except the Special Allocation Fund. All parties know the major objectives of decentralization and regional autonomy is to build people's welfare. The local government has a duty and a great responsibility to improve the welfare of the people through great authority and financial assets. But the vision of well-being is not stated explicitly in the regulation of the village. So that the programs and activities of the government's development which aims to provide benefits for the welfare and prosperity of the communities has not been fully felt.

Discussion the on spirit of autonomy, democracy and prosperity was parallel with the fundamental question of what the essence (meaning, nature, functions, and benefits) for the village people. Is just a village administrative unit of government, or simply as a region, or a village just a place to stay or a local community organization?. Is the village could not be developed and strengthened as a powerful local entities socially, politically independent, economically powerful and culturally dignified? According Hardijono (2013: 13), during this economic analysis (conventional) in general tend to dwell on the macro aspects (among others concerning the allocation of resources, poverty, income distribution) at the level of the country or between countries / regions. Still underestimate or override aspects of a more micro-level focus on the behavior of individuals or local communities (including village), because they are still very small context. Similar to Chapra (2001) in Santosa (2010: 12) states that the conventional economy indeed has gained great intellectual authority, but not the sophistication of a discipline that attract people's attention, but the contribution of what is offered by the on humanitarian disciplines in an effort to realize the objectives purpose of humanity, which at its peak will put justice and common prosperity on it. As far include social interest, the conventional economists have generally been assumed that competition would limit personal interests, and therefore encourages the fulfillment of social interest. Had a discussion of economics orientation on human welfare, then the scope is not only limited to economic variables alone, but need to pay attention to the problem of moral, psychological, social, political, demographic, history and so on. 
From the perspective of political and administrative indicate the region in Indonesia has an incredible diversity, both associated with the culture and geography and economic base. But diversity was not too difficult for positioning and shape of the area, because the whole area has been designated as an autonomous regional government by default. Rural in Indonesia, in addition to varying the plurality system, values, and culture; also has a background of a long history and diverse as well. Care should be taken in choosing the basic principles of development and rural development in Indonesia integrally. Thus institutions, including the organization, tools and legal rules require adjustments so that the opportunity for every citizen to act as an actor in the development of the core of the movement can grow in all areas of life. More Boyne (1996) "Powers the ability to innovate, experiment, and develop policies that can vary by jurisdiction. Kirlin (1996) change "government" to be "governance", and define it as capacity as the ability to make and carry through collective choices for a geographically defined group of people. In this condition there is need for a definition Kirlin local community involvement. Local independence shows the development of more appropriate when viewed as a creative process of adaptation social order rather than as a series of attempts mechanistic which refers to a plan drawn up systematically. Local self-reliance also confirmed that based organizations should be managed with more emphasis than the spirit of participation and dialogue as practiced strict control over this (Amien, 2005).

Development of rural communities to create a democratic life, both in activity and economic activity, as well as social, cultural and political activities should be based on some basic principles set forth above, also the historical background, and ethnic diversity, social, cultural, and economic had been present earlier in each village. Needs of rural development must be very diverse and between one village to another village would not have equality in their needs, so that the utilization of funds in accordance with ADD have a diversity of conditions in the village. However, in the preparation of rural development policies in general can be seen in the three groups (Haeruman, 1997), namely: Rural development is seen as a natural process, which is based on its potential and the ability of rural communities themselves. This approach minimizes interference from outside so that the changes are expected to take place in a long period. (1). Policies are not directly aimed at creating conditions that ensure the sustainability of any rural development efforts to support social and economic activities, such as the provision of facilities and supporting infrastructure (market, education, health, roads, and so forth, institutional strengthening, and protection against social and economic activities of society through legislation. 2). Policies directed at pengingkatan economic activities of rural communities. 3). Specific policies to reach people through special efforts, such as legal guarantees through legislation and guarantee the safety and convenience of the public. Different points of view can be used to examine rural development. According Haeruman (1997), there are two sides to examine rural view, namely: a). Rural development is seen as a natural process, which is based on its potential and the ability of rural communities themselves. This approach minimizes interference from outside so that the changes are expected to take place in a long period. b). The other side sees rural development as an interaction between the potential of the rural community and encouragement from the outside to accelerate rural development.

The target of rural development is the creation of the economic conditions of rural people in the strong, and able to grow independently and sustainably. Meanwhile, according to the theory of decentralization, local village is actually a part of the local government. But during development and decentralization policy is not seriously siding and responsive to the village, so that occurs village setting and just become objects of supra village project, which makes the problem of injustice, poverty and underdevelopment always attached to the people in the village. Therefore, the idea and the next village autonomy arrangement is meant to repair the damage of social, cultural, economic and political villages. Village autonomy was about to restore the livelihood base of rural communities, and sociologically about to strengthen the livelihoods of rural communities, and public entities are strong and independent association. The village has its own government authority to take care of its territory even financial management and wealth of the village has been arranged separately, as set out in the Regulation of the Minister of Home Affairs No. 4 of 2007 on Village Wealth Management. Regulation of the Minister of Home Affairs No. 35 of 2007 on Reporting and Accountability Village Government and Regulation of the Minister of Home Affairs No. 37 of 2007 on the Financial Management of the village. In the context of the management of the village budget allocation, as the institutional rules that limit human deviant behavior (humanly devised) to build the structure of the interaction of political, economic, and social in the community. 


\section{Conclusion}

Based on the discussion and construction theory, the results of this study lead to several conclusions, namely:

- -Village autonomy can be realized with good if people have enough power to accept and implement, impowered community also needs to be supported by policies and regulations are able to protect and enclose of various actions rights abuses and violations of the rules.

- -Utilization of Funds allocations new village yet fully make room for the community to develop its economy.

- -Village allocation fund budget management need rules that limit human deviant behavior (humanly devised) to build the structure of the interaction of political, economic, social and community.

- $\quad$-There are still many villages that have not been able to prepare for the management of the village fund allocation both in terms of its annual plan products, utilization and accountability.

- -Direct assistance Village Allocation Fund is more focused on physical development. So it will not be able to change the economic face of the existing rural communities.

Recommendation: Basing on the existing realities on the ground and discussions conducted theory, the researchers saw the need for some good recommendations on a theoretical level, the concept, and operational. Specifically, related to the allocation of funds village district government policy is needed in managing the village budget as financial balance formula between the government district and village. To improve the capability and expertise of human resources in the village government finance, particularly at the district level, education and training needs to be done about the accounting and finance areas. To accelerate the economic development of rural communities need to be accompanied by effective control mechanisms and followed a greater public participation. To improve the economic capacity of rural communities to enforce the village market, so that production of the communities can be a bridge for the smooth flow velocity and for the development of the village.

\section{References}

Amien, M. (2005). Kemandirian Lokal. Gramedia Pustaka Utama, Jakarta.

Abdullah, R. (2000). Pelaksanaan Otonomi luas dan Isu Federalism sebagai suatu Alternatif. Jakarta, Raja GrafindoPersada.

Boyne, G. A. (1996). Competition and Local Government: A Public Choice. Perspective. Urban Studies, 33(4-5), 703-721

Black, J. (2002). A Dictionary of Economics. Oxford University Press.

Commons, J. R. (1934). Institutional Economic: Its Place in Political Economy. Madison University of Wisconsion Press.

Dworkin, R. (1998). Butir-Butir Pemikiran Dworkin Ronald dalam Konstitusionalisme dan Pengaruhnya terhadap Konstitusionalisme Indonesia. https://rechtboy. Wordpress.com /.../butir-butirpemikiran-ronald-dworkin

Danim, S. (2002). Menjadi Peneliti kualitatif. Bandung : Pustaka Setia Forum Pengembangan Pembaharuan Desa, 2005. ADD Lahir Atas desakan Bawah. Media Pembaharuan Desa. Jakarta

Hardijono, R. (2012). Kemandirian Ekonomi Desa Melalui Kelembagaan Badan Usaha Milik Desa. Disertasi Program Doktor Ilmu Ekonomi Program Pascasarjana Universitas Brawijaya

Devas, N. R. (1999). Keuangan Pemerintah Daerah di Indonesia, UI Press, Jakarta

Hehamahua, H. (2012). Disertasi Program Doktor Ilmu Ekonomi Pasacasarjana Universitas Brawijaya Malang

Haeruman, H. (1997). Strategi Kebijakan dn Program Pembangunan Masyarakat Desa: Kearah Integrasi Perekonomian Kota - Desa. Makalah Seminar Nasional Pengembangan Perekonomian Pedesaan Indonesia. Jurusan Ilmu -ilmu Sosial Ekonomi Pertanian, Fakultas Pertanian Institut Pertanian Bogor.

Hasibuan, N. (2003). Sejarah Pemikiran Ekonomi. Jakart : Pusat Penerbit Universitas Terbuka.

Hayami, Y. \& Kikuchi, M. (1987). Dilema EkonomiDesa. Suatu Pendekatan Ekonomi TerhadapPerubahan Kelembagaan di Asia. YayasanObor Indonesia, Jakarta

Holdaway, N., Hickson, \& Heron. (1985). Dimensions of Structure: A Review and Reappraisal. Published by: Academy of Management. Stable URL: http://www.jstor.org/stable/257249 
Hoesein, B. (1993). Teori dan Praktik Pemerintahan dan Otonomi Daerah. Penerbit Grasindo Jakarta.

Ismail, M. (2007). Kritik Sosiologis Terhadap Kedudukan Individu Dalam Bangunan Teori Ekonomi Neoklasik. Makalah Pengukuhan Guru Besar Ekonomi Universitas Brawijaya Malang

Jaya, W. K. (2010). Kebijakan Desentralisasi di Indonesia Dalam Perspektif Teori Ekonomi Kelembagaan, Pidato Pengukuhan Jabatan Guru Besar dalam Ilmu Ekonomi, Universitas Gadjah Mada.

Kirlin, J. J. (1996). The Big Questions of Public Administration in a Democracy. Public Administration Review, 56(5), 416-4320.

Maryunani. (2007). Sentuhan Pembangunan Ekonomi Dalam Penguatan Perekonomian Desa di Indonesia. Makalah Pidato Pengukuhan Guru Besar dalam Bidang Ilmu Ekonomi Pembangunan, Fakultas Ekonomi Universitas Brawijaya

Mangkoesubroto, G. (1999). Ekonomi Publik, Edisi ketiga, BPFE-UGM, Yogyakarta.

Moleong, L. J. (2007). Metode Penelitian Kuaalitatif. Bandung : PT. Remaja Rosdakarya

Mawhood, P. (1983). Local Government in the Third World: the Experiences of Tropical Africa Chishester John Wiley \& Sons.

North, D. (1990). Institutions, Institutional Change and Economic Performance. Cambridge: Cambridge University Press

Peraturan Menteri Dalam Negeri Nomor 37 Tahun 2007.

Price, J. \& Mueller, C. (1986). Absenteeism and turnover among hospital employees. Greenwich, CT: JAI Press.

Rahmanta. (2009). Penataan Ruang Perdesaan Dalam Era Otonomi Daerah. Data internet. Wibsite .www repository.usu.ac.id/bitstream/123456789/768/1/09E01765.pdf.

Republik Indonesia. (2005). Peraturan Pemerintah Nomor 72 Tahun 2005 tentang Desa, Departemen Dalam Negeri, Jakarta.

Sukmadinata. (2006). Metode Penelitian Pendidikan, Remaja Rosdakarya, Bandung

Santosa, B. P. (2010). Kegagalam Aliran Ekonomi Neoklasik Dan Relevansi Aliran Ekonomi Ekonomi Kelembagaan.Makalah Pidato Pengukuhan Guru Besar Ekonomi Universitas Diponegoro Semarang. Data internet http://eprints.undip.ac.id.

Soetrisno, L. (1988). Negara dan Peranannya dalam Menentukan Pembangunan Desa yang Mandiri. Prisma No. 1 Tahun XVII Januari 1988. Jakarta

Suryaningrat, B. (1985). Ihwal Publik Administrasi.

Selznick, P. (1992). The Moral Common-wealth. Berkeley, CA: University of California Press.

Todaro, M. P. (1998). Pembangunan Ekonomi Di Dunia Ketiga Edisi Ke 6. Jakarta. Erlangga

Undang-undang No. 32 tahun 2004 tentang Pemerintahan Daerah

Undang-undang No. 33 tahun 2004 tentang Perimbangan Keuangan Pemerintah Pusat dan Pemerintah Daerah.

Yustika, A. E. (2006). Ekonomi Kelembagaan, Defenisi, Teori dan Strategi. Penerbit Bayu Media Malang. 